\title{
Business Strategy of Chemical Company Using SWOT and Business Model Canvas Approach
}

\begin{abstract}
Chemical business in water treatment has a potential growth in the future. Currently, PT A is a chemical company who leads market share in Indonesia compared to other competitors. Within next ten years, PT A should keep this level of competitiveness and improve the level of market share. Therefore, indispensable to analyze the business strategy in order to be ready to face upcoming competitiveness and opportunities. Analysis of strategy is conducted by SWOT approach. From this SWOT analysis, Internal Factor Evaluation (IFE) and External Factor Evaluation (EFE) matrix then took place to review this SWOT result. Furthermore, Business Model Canvas method is used to discuss more detail in every single block. During using Business Model Canvas, company representative is invited in Focus Group Discussion. Business Model Canvas is selected in this research due to it has comprehensive analysis about the nine variable that company running the business. From this research, it is known that company place at quadrant I of SWOT diagram. IFE and EFE score is 3.54 and 2.40, respectively. This score plots at zone IV, which means Grow and Build, in IFE-EFE matrix. These result then become an input for BMC mapping. Improvement of BMC then recommended for key resources, key partnership, key activities dan channels. Strategy generated from this research then will be a recommendation to the management. Besides, this research also become a motivation for the researcher because so far there is no particular strategy development for water treatment business in power plant based on academic point of view.
\end{abstract}

Ahmad Irwiyan $\mathrm{Haq}^{1 *}$, and Moses Laksono Singgih ${ }^{1}$ in Table 1.
Keywords-Strategy, SWOT, Business Model Canvas, Focus Group Discussion.

\section{INTRODUCTION}

Nowadays, the growth of the power generation industry has increased significantly. The electricity generation industry will not be separated from the water needs of both domestic processes and water so that the growth of this industry will also be followed by the growth of the water treatment industry.

The main product of PT A is chemical for water treatment in power plants. The company has several competitors. They consist of multinational companies such as PT A and also local companies. PT A company always emphasizes to customers that they are Multinational Company with a very strong brand both in Indonesia, regional level, and also global level. The list of chemical companies for water

\footnotetext{
${ }^{1}$ Ahmad Irwiyan Haq and Moses Laksono Singgih with Department of Technology Management, Institut Teknologi Sepuluh Nopember, Surabaya, 60111, Indonesia. E-mail: ahmad.irwiyan@gmail.com; moseslsinggih@ie.its.ac.id.
}

treatment of the electricity generation industry is presented

The company realizes that a more measurable review of the company's internal and external conditions is likely to affect the company's performance and competitiveness. Therefore, it needs to be explored further how to develop a more effective strategy to increase sales. Furthermore, what strategies can be better by using the right business model.

TABLE 1.

COMPANy List OF CHEMICAL SUPPLIER IN POWER GENERATION INDUSTRY IN INDONESIA

\begin{tabular}{ccc}
\hline \hline No & Company Name & Status \\
\hline 1 & PT. A & Multinational Company \\
2 & PT. B & Local Company \\
3 & PT. C & Multinational Company \\
4 & PT. D & Multinational Company \\
5 & PT. E & Local Company \\
6 & PT. F & Multinational Company \\
\hline \hline
\end{tabular}

Strategy is something that is related to how to be different and has a unique blend of values [1]. Reviewing the strategic advantage is more important than just competitive advantage [2]. Companies need a business model as a method to run their business [3]. A business model is a hypothesis about how companies make money in the long run, including what the company will sell, to whom, how the company will collect revenue, what technology will be used, when the company will depend on its business partners and what about costs [4] The concept of a business model is designed to visualize reality in a structured, simplified and easily understood way. In addition, it also allows a company to understand the core problems and how the company operates and how the company offers value to its customers. A business model illustrates the rationale for how organizations create, deliver, and capture value [5]. All companies need to have a business model to find out whether a company has benefits so that it can create, deliver and capture value to customers [6].

In today's competitive business world, business models can be used by organizations and companies that want to develop, innovate and make profits [7]. The business model that will be used in this study is the Business Model Canvas method. This method will be used to evaluate current strategies while determining future strategies to maintain competitiveness in the face of current markets and opportunities ahead. The Business Model Canvas approach is used in this study because it has a simple but comprehensive framework in providing an assessment of business operational components. Osterwalder \& Pigneur 
[5] emphasize that Business Model Canvas is provided to provide value and improve the performance of a business or organization [8]. In addition, Business Model Canvas is the latest strategic approach born in 2010 compared to other business strategy approaches born before that, such as Competitive Advantage [9] and Blue Ocean Strategy [10].

By looking at the studies of these researchers, this study in addition to using the Business Model Canvas approach was also combined with a SWOT analysis. The SWOT assessment is then analyzed with the IFE (Internal Factor Evaluation) and EFE (External Factor Evaluation) matrices. The Lean Canvas model initiated by Maurya does have a variable in assessing a business, but this model can only be used for start-up or entrepreneurial businesses [11]. Therefore, the combination of Business Model Canvas and IFE and IFE matrices was chosen in this study. With this method, it will be seen how the PT A company in this generation division manages every element related to business in more detail and more comprehensive.

Before analysis using the Business Model Canvas method, there needs to be other tools as inputs, namely SWOT analysis. This analysis is carried out to identify the advantages and disadvantages of the company and its ability to capture opportunities and face existing constraints [12]. Through SWOT analysis can also be done further company strategy formulation because it can be seen what is in the internal company and external environment [13].

PT A has a reliable brand in water treatment in Indonesia. Figure 1 shows the current market share.

Seeing the company's high market share and also observing the development of the growing power industry, the company feels the need to look back at the strategy in facing opportunities as well as future competition. Therefore, researchers have confidence that it is necessary to study and analyze the right strategy to maintain the existing market share of customers and opportunities in the future.

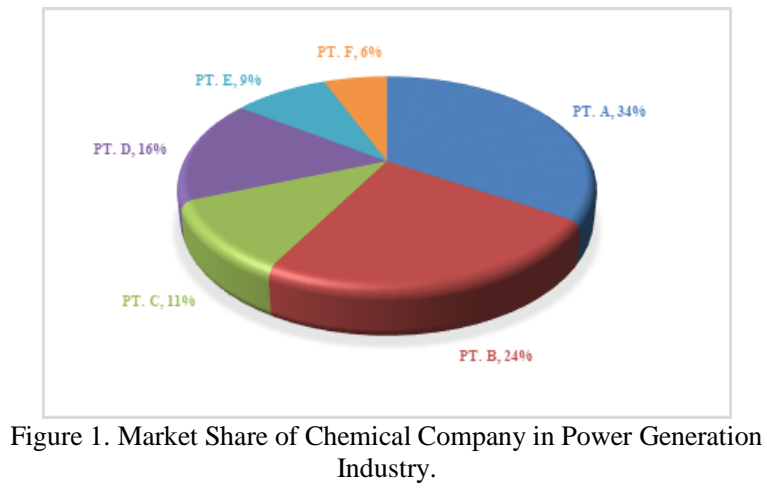

\section{LITERATURE REVIEW}

\section{A. Power Generation Industry}

The electricity generation industry is growing year by year. According to data from the ESDM Directorate General of Electricity, in 2011 the capacity of electricity generation in Indonesia was 42.457 MW. In 2017, electricity generation capacity in Indonesia reaches 60,786 MW. Within 6 years, there was an increase in the power plant capacity by $43.17 \%$ or $7.1 \%$ per year.

In the RUPTL document issued by the Directorate General of Electricity, in 2027 Indonesia will have an additional power generation capacity of 56,024 MW. This figure is almost the same as the current electricity generation capacity installed. The planned growth of generating capacity is spread in various regions as presented in Figure 2.1. In the figure, the regional division consists of five regions, namely Sumatra, Kalimantan, Sulawesi, Java-Bali-Nusa Tenggara, and Maluku-Papua. In the Sumatra region, power plants will grow by $15.990 \mathrm{MW}$ by 2027 . In the Java region, electricity generation will increase by 22,692 MW. In Sulawesi, 4599 MW will increase. In the Sulawesi region it will increase by 4,849 MW.

\section{B. Water Treatment Business in Power Generation}

The PT A company has a core business in water treatment and waste water treatment management. In this study, the subject of the research was specifically on chemical products only. Chemicals are important supporting materials in power plants. Chemicals used in plants and are for water treatment, steam processing and waste treatment. The types of chemicals found in power plants include:

- Biocide

- Coagulant

- Flocculant

- Ammonia

- Oxygen Scavenger

- Tri Sodium Phosphate

- Scale Inhibitor

- Corrosion Inhibitors

\section{SWOT Analysis}

SWOT analysis is an evaluation tool for all strengths, weaknesses, opportunities and threats from an individual or organization. The four factors that form the SWOT acronym (strength, weakness, opportunity, and threat). SWOT analysis is a framework that is often involved in the business world to analyze the factors that influence the position of a company's competitiveness in the present as well as the future [14].

According to Dyson [15], SWOT analysis is interpreted as a method used to help formulate a strategy. The term SWOT analysis is often found in the business scope. This analytical method aims to evaluate business planning and identify the company's internal potential and then compare it to the company's environment [16]. This method is not used as an analysis to get a solution to the problems faced by the company. However, the SWOT analysis only provides an evaluation of the factors that influence the effort to achieve company goals, both in the short and long term. 


\section{IFE \& EFE Matrix}

In analyzing company potential and corporate strategy formulation, the factor first analyzed was External Factor Evaluation (EFE). After that, an Internal Factor Evaluation (IFE) analysis is then carried out. The EFE matrix is a strategy tool used to understand the company's external environment in the form of opportunities and threats and use that understanding to identify and evaluate strategies to increase the level of competition in the company. As for the IFE matrix, it is a strategy tool used to evaluate the company's internal environment to reveal strengths and weaknesses at the same time [17].

\section{E. Focus Group Discussion}

FGD is conducted within this research to analyze the data. According to [18], Focus Group Discussion is a qualitative method of collecting systematic data and information and facilitated by a professional on a specific problem that is very specific through group discussions. Focus Group Discussion is one method of collecting qualitative information. The information obtained must be properly recorded so that it can be further processed in the study [19].

In terms of number there are several considerations for the effectiveness of obtaining information from this method. Too few participants did not provide interesting variations. If too much will reduce the opportunity of each participant to contribute deep thoughts. The number of participants can be reduced or added depending on the research objectives and facilities available. According to [20] one discussion group can consist of 4 to 8 people.

\section{F. Business Model Canvas (BMC)}

The business model must be shaped according to market developments faced, technological developments and legal structures that exist at that time [21]. There are several tools that can be used in evaluating a company's business model, one of which is quite simple but considered very comprehensive and powerful, namely Business Model Canvas. The business model canvas is a shared language to describe, visualize, assess, and change business models [5].

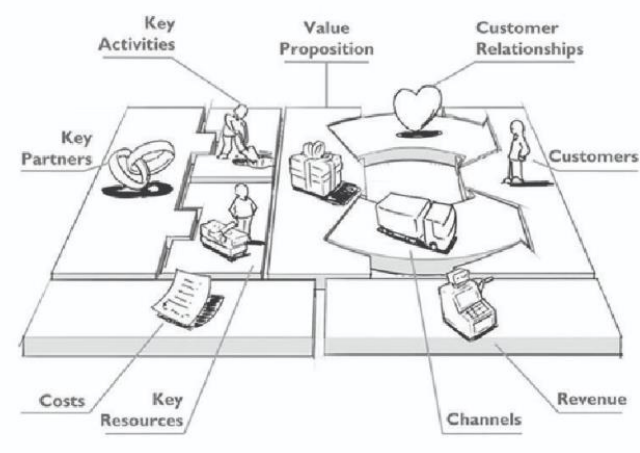

Figure 2. Business Model Canvas template
According to [5], the Business Model Canvas has a characteristic with 9 (nine) block models which, if put together, will become a single business entity. These nine blocks as below:

1) Customer Segment.

The first step of mapping the Business Model Canvas is aimed at the customer section. Companies need to identify market groups that are corporate customers. In running the business wheel, the organization must first determine who should be served and also who should be ignored.

2) Value Preposition

Secondly, companies need to record what values they want to convey to customers. Value does not always have to be a product advantage, but can also be created through experience, brand strength, history, and so on. Value Proposition is the benefits offered by a company or organization to the market segments served.

\section{3) Channel}

Channels are tools and mediums that are used by companies or organizations to communicate with customers and achieve targets set at the customer. In its implementation, an important point in this case is how the value provided by the company is believed to arrive at the customer as a benefit for them.

\section{4) Customer Relationship}

Customer relationship is how companies maintain and build short-term and long-term relationships with customers that provide benefits through the provision of services that have added value and satisfaction for them.

\section{5) Revenue Stream}

Revenue Stream represents money earned from the customer. If the customer is the heart of a business, then the Revenue Stream element is his vein.

\section{6) Key Resources}

Key Resources describes the most important assets a company has to create a business model. These resources then create and offer value prepositions to customers, get them as the company's market, maintain good relationships with customer segments, and get revenue from them.

\section{7) Key Activities}

Key activities are the most important activities that companies must do to run their business models. Just like Key Resources, Key Activities then create and offer value prepositions to customers, get them as the company's market, maintain good relationships with customer segments, and get revenue from them.

\section{8) Key Partnership}

Partnerships are the foundation of many business models. Companies make alliances to optimize their business models, reduce risk, or obtain resources.

\section{9) Cost Structure}

This describes the most important costs incurred when operating under certain business models. Creating and sending values, maintaining Customer Relationship, and generating income are all charged. 
The $1^{\text {st }}$ International Conference on Business and Management of Technology (IConBMT)

August 3rd 2019, Institut Teknologi Sepuluh Nopember, Surabaya, Indonesia

\section{Methodology}

To be able to obtain results that are in accordance with the objectives of this study, this study uses data collection techniques as follows:

Observation - Observation is carried out by conducting a direct observation of the conditions that exist within the company. The quantitative data obtained from these observations are sales data and market share. Qualitative observation data includes strengths, weaknesses, threats and opportunities owned by the company.

Focus Group Discussion - Focus Group Discussion (FGD) is the media that will be carried out in this study to capture input from the teams involved in sales operations. The FGD will be attended by account managers, area managers and the district manager. From these circles a discussion will be held on the strengths, weaknesses, threats and opportunities of the company along with weighting and ranking. With the existence of FGDs, it is expected that the inputs that form the basis of the strategy development will become more comprehensive. The FGD will be conducted by direct meeting at a certain time. However, if it is felt that it is not possible because of their respective activities, the FGD will be conducted through Webex tools, namely a kind of teleconference media that allows audio and visuals to be accessed by FGD participants directly.

Interview - Interviews are needed to complete the information obtained through observations and focus group discussions. The interview technique in this study was carried out by a semi-structured method. Semi-structured interviews are interview processes that use guidance on the development of interview topics so that they are more flexible. Interviews are conducted by giving questions directly to the speakers. The resource persons will be deliberately selected by considering the resource persons expertise in the field and scope of this research.

\section{A. Data Analysis}

The use of SWOT analysis is conducted to analyze the company's internal and external factors so that strengths and weaknesses can be identified as well as the threats and opportunities that exist. The preparation of a list of strengths and weaknesses will involve the customer so that the company will be confirmed that what is needed by the customer is already owned by the company or not. If the company does not have something that is of concern to the customer, then it becomes a weakness. Conversely, if it is already owned by the company, then it is the strength of the company. Based on the results of the SWOT analysis, several considerations will be obtained for setting strategy.

The results of data collection are further processed using the method of making IFE and EFE Matrix. Then, the matrix is mapped in the SWOT diagram. From the processing, what internal and external factors will be produced that will become the company's excellence in increasing future competitiveness. In making IFE and EFE matrices, it is necessary to weight and assess each company's strengths and weaknesses as well as the threats and opportunities that exist.

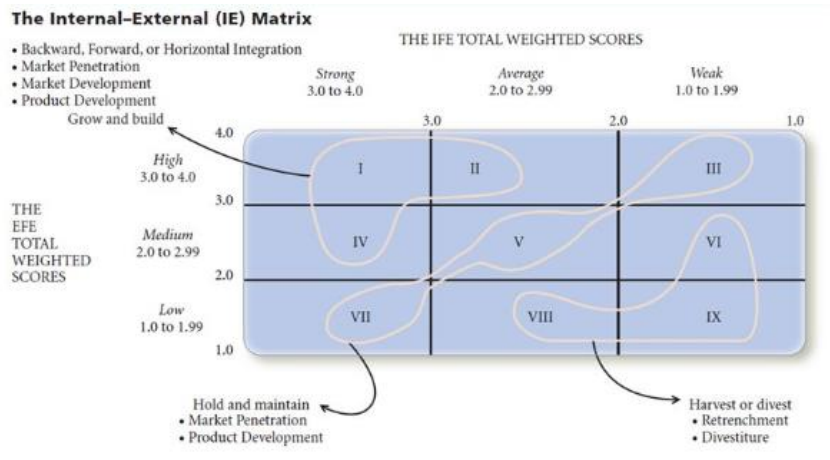

Figure 3. IFE \& EFE Matrix

IFE and EFE factor values give birth to certain quadrants in the Business Model Canvas block. The position of the company that is in a certain quadrant as an IFE and EFE matrix result produces a strategy recommendation that will be used as a reference for Business Model Canvas inputs. In this stage, the FGD was carried out again in the company's internal to discuss the details of items entered into 9 (nine) blocks in the Business Model Canvas as shown in Figure 2

\section{RESUlTS AND DISCUSSION}

From the results of interviews, several indicators were obtained to be used as further assessments of the company's internal and external analysis. some of these indicators can be seen in Table 2 and 3.

TABLE 2.

INTERNAL INDICATOR

\begin{tabular}{cl}
\hline \hline No. & \multicolumn{1}{c}{ Internal Indicator } \\
\hline 1 & Multinational company \\
2 & Global brand \\
3 & Have a production factory in Indonesia \\
4 & Have a branch office in major cities in Indonesia \\
5 & X-Generation that survives in company \\
6 & Good technical sales staff \\
7 & Internet based automation technology \\
8 & The price of the product is relatively expensive. \\
9 & There is an experienced support team \\
10 & The Supply Chain Management system is still manual \\
11 & MTO Policy (Make To Order) \\
12 & Flexibility in making new products \\
\hline \hline
\end{tabular}

TABLE 3.

EXTERNAL INDICATOR

\begin{tabular}{cl}
\hline \hline No. & \multicolumn{1}{c}{ External Indicator } \\
\hline 1 & Rapid market growth \\
2 & Good choice of prospective employees \\
3 & Internet of things technology is rife \\
4 & The data network has penetrated into the area \\
5 & The internet is getting faster \\
6 & Good government support regarding zero waste \\
7 & The price of raw material rises \\
8 & Price competition per unit \\
9 & Dollar exchange rate is not stable \\
10 & Supplier-side monopoly \\
11 & Cost sensitive on the customer side \\
12 & Lack of understanding of the importance of water quality \\
\hline \hline
\end{tabular}


The customer sample is taken as many as $\mathrm{n}$ of the employee population that relates to the customers. The population is 92 (ninety-two) which includes technical sales, account managers and area managers. Sampling in this study was carried out by Slovin formula as below

$$
n=\frac{N}{1+N \alpha^{2}}
$$

$\mathrm{n}=$ number of samples

$\mathrm{N}=$ population

$\alpha=$ significance level

From the formula, with a significance level of $10 \%$, the samples to be used in this study are

$$
n=\frac{92}{1+92(0.1)^{2}}=48
$$

To get a more quantitative assessment of the survey results, a Focus Group Discussion was held. In this FGD session, it was conducted through Webex or teleconference because it was difficult to gather managers in one place and at a certain time. On the other hand, it is also more effective and more efficient. FGD participants included.

1. District Manager

2. Area Manager - Western Region

3. Area Manager - Eastern Region

4. Account Manager - Western Region

5. Account Manager - Eastern Region

The FGD was conducted in 2 (two) stages. First, it is carried out in order to determine the assessment of internal and external analysis in making the SWOT matrix and IE matrix. The second is in the context of discussing the results of the SWOT matrix and IE matrix in evaluating existing Business Model Canvas and improving the new Business Model Canvas (BMC) strategy.

\section{A. SWOT Analysis}

The SWOT analysis in this study was obtained by discussion and brainstorming together with the managers at the time of the FGD implementation. The following are the results of the SWOT matrix at Table 4.

To assess and determine the position of the company's strength in order to find out which strategy is appropriate and to deepen the analysis, this research carried out SWOT diagram mapping. The assessment was carried out together with the managers during the FGD implementation. The results of the SWOT diagram can be seen in Table 5.

It can be seen from the formulation that values are generated for each strength, weakness, opportunity and threat. Mapping the SWOT diagram as follows:

B. Coordinate internal analysis (total strength score - total weakness score)

C. External analysis coordinates (total opportunity score total threat score)

The result of the SWOT diagram formulation indicate that the company strategy is recommended referring to quadrant I that can be seen at Figure 5.

The formulation of this research was carried out together with the managers during the FGD implementation. With the writer scenario and each manager gives weight and rating then the results are on average. The results of the formulation of IFE and EFE matrices can be seen in Table 4.

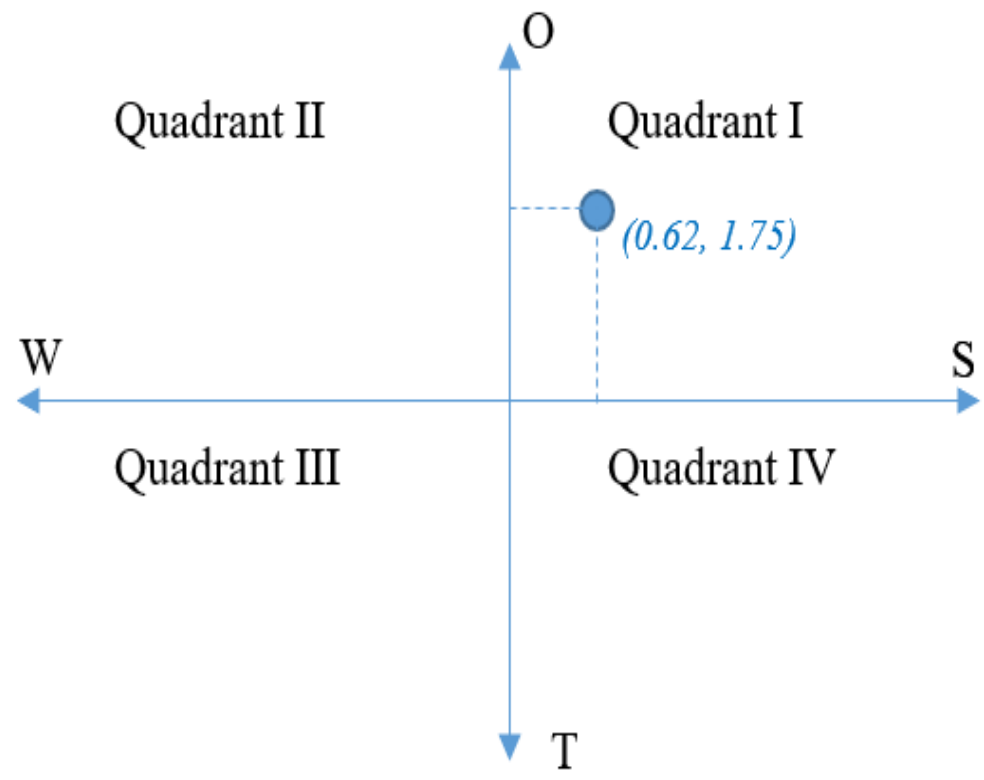

Figure 4. SWOT Analysis Diagram [22] 
The $1^{\text {st }}$ International Conference on Business and Management of Technology (IConBMT)

August 3rd 2019, Institut Teknologi Sepuluh Nopember, Surabaya, Indonesia

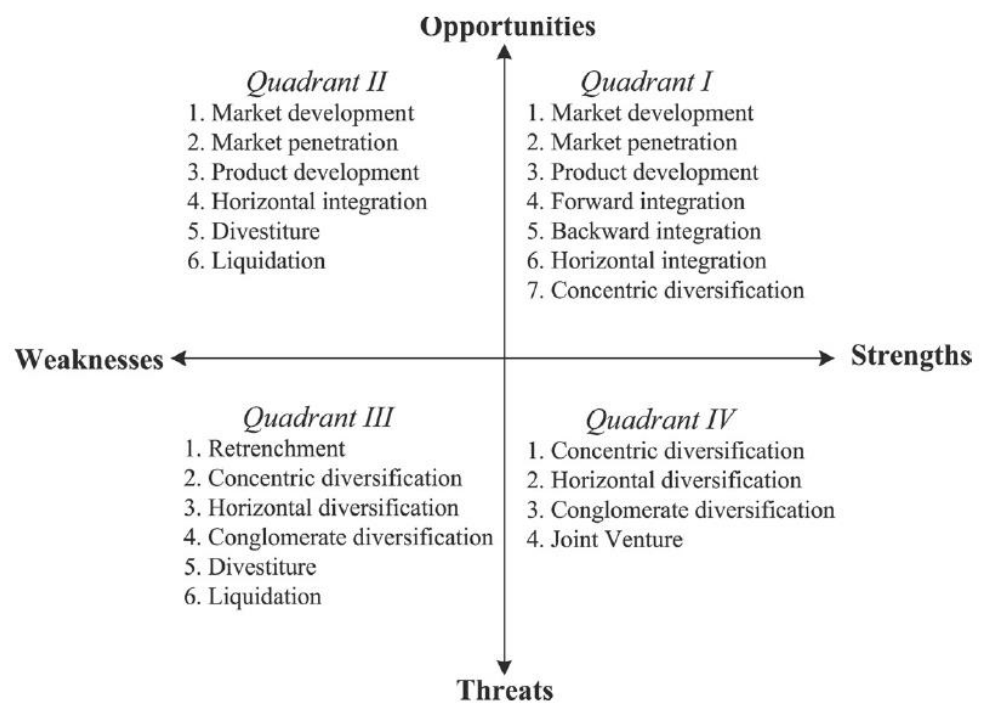

Figure 5. Diagram SWOT and Its Description

TABLE 3.

SWOT MATRIX RESULT

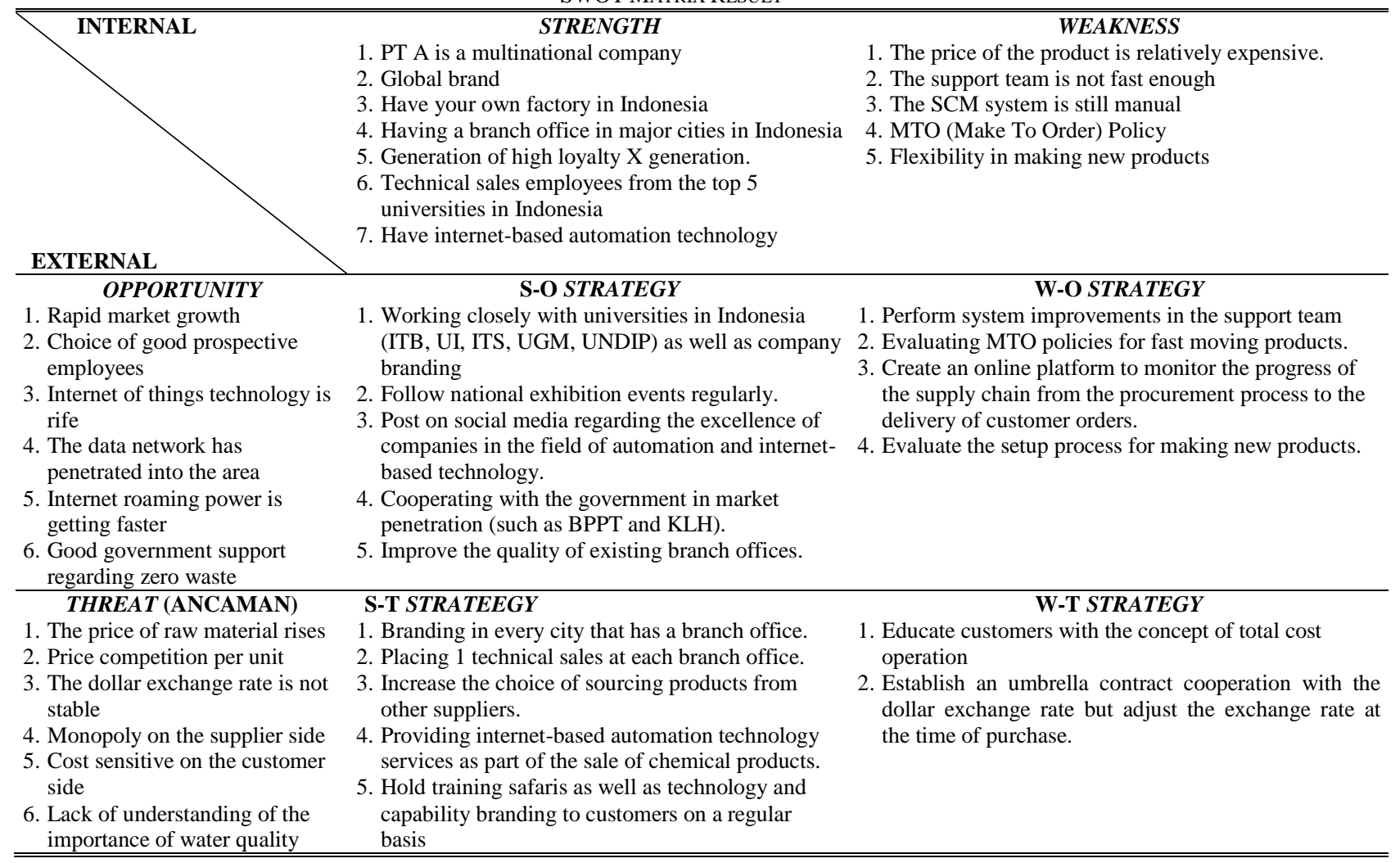

TABLE 4.

SWOT ANALYSIS

\begin{tabular}{lccc}
\hline \hline \multicolumn{1}{c}{ STRENGTH } & WEIGHT & RATING & SCORE \\
\hline Multinational company & $27 \%$ & 4 & 1.07 \\
Global brand & $18 \%$ & 4 & 0.73 \\
Have a production factory in Indonesia & $13 \%$ & 4 & 0.52 \\
Have a branch office in major cities in Indonesia & $11 \%$ & 3 & 0.33 \\
X-Generation that survives in company & $4 \%$ & 3 & 0.12 \\
Good technical sales staff & $16 \%$ & 4 & 0.62 \\
Internet based automation technology & $12 \%$ & 4 & 0.47 \\
& $\mathbf{1 0 0 \%}$ & & $\mathbf{3 . 8 5}$ \\
\hline
\end{tabular}




\begin{tabular}{lccc}
\hline \multicolumn{1}{c}{ WEAKNESS } & WEIGHT & RATING & SCORE \\
\hline The price of the product is relatively expensive. & $33 \%$ & 3 & 0.99 \\
There is an experienced support team & $10 \%$ & 3 & 0.30 \\
The Supply Chain Management system is still manual & $20 \%$ & 3 & 0.60 \\
MTO Policy (Make To Order) & $23 \%$ & 4 & 0.92 \\
Flexibility in making new products & $14 \%$ & 3 & 0.43 \\
\multicolumn{1}{c}{ OPPORTUNITY } & $\mathbf{1 0 0 \%}$ & & $\mathbf{3 . 2 3}$ \\
\hline \multicolumn{1}{c}{ THEIGHT } & RATING & SCORE \\
\hline Rapid market growth & $28 \%$ & 4 & 1.10 \\
Good choice of prospective employees & $22 \%$ & 3 & 0.66 \\
Internet of things technology is rife & $21 \%$ & 3 & 0.63 \\
The data network has penetrated into the area & $8 \%$ & 3 & 0.25 \\
The internet is getting faster & $8 \%$ & 3 & 0.25 \\
Good government support regarding zero waste & $13 \%$ & 3 & 0.38 \\
& $\mathbf{1 0 0 \%}$ & & $\mathbf{3 . 2 7}$ \\
\hline & $\mathbf{B O B O T}$ & $\mathbf{R A T I N G}$ & $\mathbf{S C O R E}$ \\
\hline The price of raw material rises & $24 \%$ & 2 & 0.48 \\
Price competition per unit & $13 \%$ & 2 & 0.27 \\
Dollar exchange rate is not stable & $15 \%$ & 2 & 0.30 \\
Supplier-side monopoly & $5 \%$ & 1 & 0.05 \\
Cost sensitive on the customer side & $21 \%$ & 1 & 0.21 \\
Lack of understanding of the importance of water quality & $\mathbf{2 2 \%}$ & 1 & 0.22 \\
The price of raw material rises & $\mathbf{1 0 0 \%}$ & & $\mathbf{1 . 5 2}$ \\
\hline \hline
\end{tabular}

TABLE 5.

IFE AND EFE FORMULATION

\begin{tabular}{|c|c|c|c|}
\hline STRENGTH & WEIGHT & RATING & SCORE \\
\hline Multinational company & $13.40 \%$ & 4 & 0.54 \\
\hline Global brand & $9.10 \%$ & 4 & 0.36 \\
\hline Have a production factory in Indonesia & $6.50 \%$ & 4 & 0.26 \\
\hline Have a branch office in major cities in Indonesia & $5.50 \%$ & 3 & 0.17 \\
\hline $\mathrm{X}$-Generation that survives in company & $2.00 \%$ & 3 & 0.06 \\
\hline Good technical sales staff & $7.80 \%$ & 4 & 0.31 \\
\hline Internet based automation technology & $5.70 \%$ & 4 & 0.23 \\
\hline WEAKNESS & WEIGHT & RATING & SCORE \\
\hline The price of the product is relatively expensive. & $16.50 \%$ & 3 & 0.5 \\
\hline There is an experienced support team & $5.00 \%$ & 3 & 0.15 \\
\hline The Supply Chain Management system is still manual & $10.00 \%$ & 3 & 0.3 \\
\hline MTO Policy (Make To Order) & $11.50 \%$ & 4 & 0.46 \\
\hline \multirow[t]{2}{*}{ Flexibility in making new products } & $7.00 \%$ & 3 & 0.21 \\
\hline & $100 \%$ & & 3.54 \\
\hline OPPORTUNITY & WEIGHT & RATING & SCORE \\
\hline Rapid market growth & $13.80 \%$ & 4 & 1.1 \\
\hline Good choice of prospective employees & $11.00 \%$ & 3 & 0.66 \\
\hline Internet of things technology is rife & $10.50 \%$ & 3 & 0.63 \\
\hline The data network has penetrated into the area & $4.20 \%$ & 3 & 0.25 \\
\hline The internet is getting faster & $4.20 \%$ & 3 & 0.25 \\
\hline Good government support regarding zero waste & $6.30 \%$ & 3 & 0.19 \\
\hline THREAT & WEIGHT & RATING & SCORE \\
\hline The price of raw material rises & $12.00 \%$ & 2 & 0.24 \\
\hline Price competition per unit & $6.70 \%$ & 2 & 0.13 \\
\hline Dollar exchange rate is not stable & $7.50 \%$ & 2 & 0.15 \\
\hline Supplier-side monopoly & $2.30 \%$ & 1 & 0.02 \\
\hline Cost sensitive on the customer side & $10.50 \%$ & 1 & 0.11 \\
\hline \multirow[t]{2}{*}{ Lack of understanding of the importance of water quality } & $11.00 \%$ & 1 & 0.11 \\
\hline & $100 \%$ & & 2.4 \\
\hline
\end{tabular}

The formulation of the IFE and EFE matrix is a stage of summarizing information as a basic input (M. E. David \& David, 2016). The first step in conducting IFE \& EFE is identification of internal and external factors.

From the formulation of IFE and EFE matrix scores for IFE and EFE are $\mathbf{3 . 5 4}$ and 2.40. This score is then plotted into the IFE and EFE matrix diagrams to then see the recommended strategy. From Figure 2, the direction of the strategy is 'Grow and Build'. The 'Grow and Build' strategy includes:

- Market penetration,

- Market development,

- Product development,

- Forward integration.

D. Business Model Canvas

In the company BMC has never been formulated. The FGD results on the existing conditions of the company help in 
The $1^{\text {st }}$ International Conference on Business and Management of Technology (IConBMT)

August 3rd 2019, Institut Teknologi Sepuluh Nopember, Surabaya, Indonesia

seeing a clearer perspective on the condition of each block. So if there is something that needs to be done, improvement becomes clearer and easier.

From the results of the SWOT diagram and the IFE-EFE diagram, then the direction of the strategy recommendations is used as the basis for input of 9 (nine) blocks in the Business Model Canvas. In the preparation of this BMC, a Focus Group Discussion was held with managers. The results of this formulation can be seen in Table 7.

From the results of the existing BMC mapping and input from the SWOT and IFE-EFE diagrams, then the results of the new BMC formulation are obtained. The new item of strategy in these four building block is in blue font. The strategy set forth in the new BMC boils down to the improvement of 4 (four) main building blocks, namely key resources, key partnerships, key activities and channels. The additional of the four blocks will then affect the cost structure block because there will be costs incurred for this change. In addition, the value preposition also increases to increase the value in the market as part of the purpose of repairing four main blocks.

TABLE 6.

BUSINESS MODEL CANVAS EXISTING.

\begin{tabular}{|c|c|c|c|c|}
\hline \multirow{10}{*}{$\begin{array}{l}\text { Key Partnership } \\
\text { 1. Supplier } \\
\text { 2. Forwarder } \\
\text { 3. Third party } \\
\text { Laboratorium } \\
\text { 4. Recruitment Agent } \\
\text { 5. Local Distributor }\end{array}$} & Key Activities & Value Preposition & Customer Relationship & Customer Segment \\
\hline & 1. Chemical Production & 1. Total Cost Operation & 1. Direct selling & 1. PLN \\
\hline & 2. Maintaining customer existing & 2. Generate saving cost & 2. Local Distributor & 2. IPP \\
\hline & $\begin{array}{l}\text { 3. Selling and delivering product to } \\
\text { customer }\end{array}$ & 3. Water Solution & $\begin{array}{l}\text { 3. Open Bid } \\
\text { 4. Direct appointment }\end{array}$ & $\begin{array}{l}\text { 3. Contractor of } \\
\text { Power Plant. }\end{array}$ \\
\hline & $\begin{array}{l}\text { 4. Bidding to prospect or existing } \\
\text { customer }\end{array}$ & & & \\
\hline & Key Resources & & Channel & \\
\hline & 1. Production plant & & 1. Alumni network & \\
\hline & 2. Global Brand & & 2. Existing customer. & \\
\hline & 3. Sales and Support team. & & 3. Coorporate Account & \\
\hline & $\begin{array}{l}\text { 4. Data } C R M \text { (Customer Relation } \\
\text { Management) }\end{array}$ & & & \\
\hline
\end{tabular}

Cost Structure

1. Raw material

2. Production cost

3. Delivery cost

4. Training
Sales value of chemical product.

\begin{tabular}{|c|c|c|c|c|}
\hline Key Partnership & $\underline{\text { Key Activities }}$ & Value & Customer & C Customer Segment \\
\hline 1. Supplier & 1. Chemical Production & Preposition & Relationship & 1. PLN \\
\hline 2. Forwarder & 2. Maintaining customer existing & 1. Total Cost & 1. Direct selling & 2. IPP \\
\hline 3. Laboratorium third & 3. Selling and delivering product to customer & Operation & 2. Local Distributor & 3. Contractor of Power \\
\hline 4. Recruitment Agent & 5. Collaboration with startup apps company & cost & 4. Direct appointment & \\
\hline 5. Local Distributor & 6. Cooperation penetration with company and & 3. Water Solution & 5. Problem solving & \\
\hline 6. Consultant Supply & university/college. & 4. Water 4.0 leader & & \\
\hline 7. Start up application & customers & & & \\
\hline company & 8. Follow national exhibition & & & \\
\hline $\begin{array}{l}\text { 8. University-College } \\
\text { (ITB, UI, UGM, ITS, } \\
\text { UNDIP) }\end{array}$ & $\begin{array}{l}\text { 9. Being interviewees in media. } \\
\text { 10. More frequeent to share in social media and } \\
\text { linkedin. }\end{array}$ & & & \\
\hline & Key Resources & & Channel & \\
\hline & 1. Production plant & & 1. Alumni network & \\
\hline & 2. Global Brand & & 2. Existing customer. & \\
\hline & 3. Sales and Support team. & & 3. Coorporate & \\
\hline & 4. Data $C R M$ (Customer Relation Management) & & Account & \\
\hline & 5. Linkedin account of customer. & & 4. Media Sosial & \\
\hline & 6. Social media account of customer (personal). & & 5. Linkedin & \\
\hline & edia account of customer (company). & & & \\
\hline Cost Structure & & Revenue Stream & & \\
\hline 1. Raw material & & Sales value of $\mathrm{ch}$ & mical product. & \\
\hline 2. Production cost & & & & \\
\hline 3. Delivery cost & & & & \\
\hline 4. Training & & & & \\
\hline
\end{tabular}




\section{CONCLUSIONS}

The conclusions from the results of this study are as follows:

1) Results of SWOT formulation

- From the results of the SWOT analysis, the company currently has an internal indicator value of 0.62 and an external indicator of 1.75 .

○ This point places the company in quadrant I on the SWOT diagram. Quadrant I gave birth to recommendations for companies in the form of positions in quadrant I, namely aggressive strategy zones.

- This aggressive strategy includes market development, market penetration, product development, forward integration, backward integration, and horizontal integration.

1) Results of the formulation of the IFE-EFE Matrix

$\circ$ From the results of internal and external analysis through IFE-EFE matrices and diagrams, companies have IFE 3.54 and EFE 2.40 values.

O This value places the company in zone IV on the IFEEFE diagram. This zone recommends that companies do the Grow and Build strategy.

o This Grow and Build strategy includes market penetration, market development, product development and forward integration.

2) Results of the reformulation of Business Model Canvas.

$\circ$ The results of the SWOT and IFE-EFE analysis of the company produced a strategy recommendation as outlined in the Business Model Canvas block.

- The design changes of the Business Model Canvas include key resources, key partnerships, key activities, and channels.

- These design changes have an impact on the company's value preposition and cost structure.

\section{REFERENCE}

[1] M. E. Porter, "What is Strategy?," Harvard Business Review, pp. 61-78, 1996.

[2] K. Chaharbaghi and R. Lynch, "Sustainable competitive advantage: towards a dynamic resource-based strategy," Manag. Decis., vol. 37, no. 1, pp. 45-50, Feb. 1999.
[3] A. Afuah and C. L. Tucci, Dynamics of Internet Business Models: Text and Cases, 2nd ed. Boston: McGraw-Hill, 2003.

[4] S. Kaplan, "Experimenting with Business Models in the Real World," in The Business Model Innovation Factory, Hoboken, NJ, USA: John Wiley \& Sons, Inc., 2015, pp. 149-164.

[5] A. Osterwalder and Y. Pigneur, Business Model Generation. New Jersey: John Wiley \& Sons Inc, 2010.

[6] J. Margetta, "Why Business Models Matter," Harvard Business Review, pp. 86-92, May-2002.

[7] A. Maurya, Running Lean: Iterate from Plan A to a Plan That Works. O'REILLY, 2012.

[8] B. D. H. Coes, "Critically Assessing the Strengths and Limitations of the Business Model Canvas.," University of Twente, 2014

[9] M. E. Porter, Competitive Advantage: Creating and Sustaining Superior Performance. New York: The Free Press, 1985.

[10] W. C. Kim and R. Mauborgne, Blue Ocean Shift. Verlag Franz Vahlen $\mathrm{GmbH}, 2018$.

[11] A. Abdoun and J. Ibrahim, "Business model canvas, the lean canvas and the strategy sketch: Comparison," Int. J. Sci. Eng. Res., vol. 9, no. 1, pp. 871-889, 2018.

[12] S. D. Kalpande, R. C. Gupta, and M. D. Dandekar, "A SWOT analysis of small and medium scale enterprises implementing total quality management," Int. J. Business, Manag. Soc. Sci., vol. 1, no. 1, pp. 59-64, 2010.

[13] O. Arslan and I. D. Er, "SWOT analysis for safer carriage of bulk liquid chemicals in tankers," J. Hazard. Mater., vol. 154, no. 1-3, pp. 901-913, Jun. 2008.

[14] A. "Skip" Rizzo and G. J. Kim, "A SWOT Analysis of the Field of Virtual Reality Rehabilitation and Therapy," Presence Teleoperators Virtual Environ., vol. 14, no. 2, pp. 119-146, Apr. 2005.

[15] R. G. Dyson, "Strategic development and SWOT analysis at the University of Warwick," Eur. J. Oper. Res., vol. 152, no. 3, pp. 631-640, Feb. 2004.

[16] N. Piercy and W. Giles, "Making SWOT Analysis Work," Mark. Intell. Plan., vol. 7, no. 5/6, pp. 5-7, May 1989.

[17] C. W. L. Hill and G. R. Jones, Strategic Management: An Integrated Approach, 9. ed. Mason Ohio: South-Wester, 2010.

[18] P. van Euwijk and Z. Angehrn, "How to ... conduct a Focus Group Discussion (FGD).” 2017.

[19] Y. Afiyanti, "Focus Group Discussion (Diskusi Kelompok Terfokus) sebagai Metode Pengumpulan Data Penelitian Kualitatif," J. Keperawatan Indones., vol. 12, no. 1, pp. 58-62, Mar. 2008

[20] J. Kitzinger, "Qualitative research. Introducing focus groups.," $B M J$, vol. 311, no. 7000, pp. 299-302, Jul. 1995.

[21] D. J. Teece, "Business Models, Business Strategy and Innovation," Long Range Plann., vol. 43, no. 2-3, pp. 172-194, Apr. 2010

[22] F. Rangkuti, Analisa SWOT Teknik Membedah Kasus Bisnis. Jakarta: Gramedia Pustaka, 2005. 